\title{
Learning from Police Deaths on Duty: A Case Study
}

\author{
Tim Prenzler
}

\begin{abstract}
This paper provides an in-depth study of one police officer death on duty in Australia. The paper draws primarily on the detailed Coroner's inquest and final report into the death of Constable Brett Irwin, who was fatally shot by a career criminal when attempting to execute a warrant. The Coroner found that Irwin's death was highly preventable. The findings have vital implications for police officer safety in many jurisdictions. They support and embellish the findings from quantitative research: that police must take an extremely cautious and highly organised approach to the routine task of arrest by warrant. In analysing the inquest, the paper goes further, emphasising how computer-based criminal intelligence should feed into standardised risk management strategies and a much lower threshold for calling in special operations teams.
\end{abstract}

\section{Background}

Police work has amongst the highest occupational homicide rates and suffers from high levels of fatal accidents. Many thousands of police officers die around the world each year. Some agencies have particularly high death rates. In South Africa, for example, 109 officers died on duty in 2008-09 (South Africa Police Service, 2009). In 2008, 130 police officers lost their lives in United Nations peace keeping operations, the highest number on record (United Nations Secretary General, 2009). In the United States, in 2009, 125 officers were killed. This represented a decline of $6 \%$ from the previous year but it included 'a disturbing rise in the number of officers shot and killed' (National Law Enforcement Officers Memorial Fund, 2009, p. 1). In the United Kingdom, 152 officers are on record as the victims of homicides while on duty (Police Roll of Honour Trust, 2010). A study of occupational fatalities in Australia showed that the police rate was just over twice the general workforce rate (National Occupational Health and Safety Commission, 1999a, p. 4). Australian police were also in the top three groups for work-related homicides, along with taxi drivers and security guards; and this is a common statistic internationally (National Occupational Health and Safety Commission, 1999b, p. 9; Smith \& Webster, 2005).

Despite the salience of fatal risks as a feature of police work there is very little research on the topic. Much of the literature on officer safety is focused on preventing non-fatal assaults, although this work has implications of relevance to fatalities. For example, Kaminski and Sorensen's (1995) study of assault-related injuries recommended correcting officers' misleading perceptions about risk and improving training in unarmed defensive tactics. Smith, et al. (2009) found that both suspect and officer injuries were significantly reduced when officers deployed capsicum spray and tasers rather than direct physical force. However, this research did not specifically address fatal encounters.

The small number of studies of police homicides has produced some useful findings. In a review article, Mayhew (2001) reported that police homicides frequently involved offenders with personality disorders and victims (police) who underestimated the risks they faced from offenders (relying too much on negotiation) or who breached procedures (such as failing to wait for back-up) (see also Chapman, 
1997; Kurby, 2004). Research also shows that the large majority of police officer deaths from attacks result from injuries from firearms and occur in the following situations: arrests, interdicting in robberies, responding to disturbance and domestic violence calls, traffic stops, and investigating reports of suspicious persons (Edwards, 1996; Federal Bureau of Investigation, 2007).

In one of the few national studies on police deaths available, Allard and Prenzler (2009) collected official data on all officer deaths in Australia from the establishment of police departments in the $19^{\text {th }}$ century to 2007. Of the 643 cases identified, approximately three-quarters were found to be 'accidental' and one quarter the result of an 'attack'. The researchers found that officer fatalities had been declining as a proportion of police numbers since the 1960s as a result of improvements in procedures and technology. At the same time, the research indicated that further reductions in fatalities were obtainable through stricter application of a wider range of prevention strategies. A focus on preventing police deaths would also most likely lead to reductions in injuries. Key recommendations included curtailing speeding in police vehicles; keeping police off the road at vehicle stops and roadblocks; and better risk management procedures in arrests, executing warrants, raids and sieges (see also Prenzler, 2006).

\section{Method}

A study of police deaths normally considers variables such as physical location, time of day, the incident responded to and types of weapons. The setting is viewed as a key source of data about variables that can be modified to reduce opportunities for offences or accidents. The conceptual framework for this approach is provided by 'situational crime prevention', with its focus on 'the settings for crime' and crimerelated problems and on effective preventive interventions such as 'target hardening', 'target removal' and 'rule setting' (Clarke and Eck, 2003).

Coroner reports represent a rich source of situational data about police deaths. Inquests are highly systematic rigorous enquiries conducted in an open court. Coroners make use of expert testimony, background investigations, eye witness testimony, re-enactments and empirical measurements. They also normally contain a section where the Coroner makes recommendations for preventing deaths in the future (e.g., Coroners Act 2003 (Queensland), s.46). In most advanced democracies inquests are considered to be highly independent and objective in their approach, and capable of countering defensive biases by government departments and corporations (Pelfrey and Covington, 2007).

Because Coroner reports are data rich and deal with the minutiae of a single incident they are particularly useful for case study research. Case studies lack statistical validity. However, they can reveal aspects of a problem that might not otherwise come to light in a quantitative study. Case studies are particularly useful when the conclusions produced from the in-depth analysis are related to quantitative studies to enrich the overall body of scientific knowledge. Prima facie, the death of Constable Brett Irwin in Brisbane in 2007 represented such a case. Irwin was fatally shot by a career criminal while attempting to execute a warrant. The Press were quick to seize on indicators of procedural failings that contributed to the death - including police ignoring warnings that the offender was known to be obsessed with guns and wanted 
to die in a shoot-out with police (Meade, 2007; Murray and Doneman, 2007) - and this type of fatality represents a category of police deaths identified in the quantitative literature in the area of attack while conducting an arrest (see above).

The Queensland State Coroner's report on Irwin's death was published on October 6 2009. This is a publicly available report. In relation to the present study, a letter requesting access to the transcript of the inquest, the police report and any other relevant documents held by the Coroner was sent on 23 October 2009. Full access to the materials was authorised in a letter from the Coroner on November 242009. Copies of the police summary report and investigative report were subsequently provided, and the researcher also attended the Coroner's office to inspect the transcript. Newspaper articles on the death were also collected through a search of the electronic newspaper database Factiva. In all, the primary research for the study made use of the 18 page Coroner's report, the nine page summary police report, the 68 page investigative report (including a covering memo and a summary of the post mortem examination), the 151 page transcript of the hearing, and 33 newspaper reports.

\section{The fatal sequence of events}

The following summarises the immediate sequence of events that was found by the Coroner to have led to the death of Constable Irwin.

1. Soon after 7.20pm on 18 July 2007 Craig Semyraha, in the company of an acquaintance, committed an armed robbery at a motel in the suburb of Kippa-Ring on Brisbane's northside.

2. The offenders divided the proceeds at the home of a friend. Semyraha and a female acquaintance then went to his de facto's home in a nearby suburb, arriving around 9.30pm and consuming amphetamines.

3. Soon after 10.30pm Constable Irwin and another officer (Officer A) drove to the house in order to execute a warrant for Semyraha's arrest for his failure to appear at a magistrate's hearing the previous month. The officers were unaware that Semyraha had committed the motel robbery.

4. Officer A knocked on the door of the house. When there was no response Irwin went to the rear of the property and entered the house through the back door. Some words were spoken between Irwin and Semyraha, a short struggle ensued and a shot was fired.

5. Officer A retreated to the police vehicle and called for assistance. The scene was attended by the Special Emergency Response Team (SERT) and police negotiators. Following some communication between negotiators and Semyraha, two women and two children left the house.

6. At 1.15am a shot was heard coming from within the house. SERT officers entered and found Semyraha in the kitchen. He had a gunshot wound to the head and was transferred to a hospital. Constable Irwin was found deceased in the front yard. 
7. The area was declared a crime scene and secured, and the investigation into the death began with a forensic examination of the premises.

Background factors

The following sets out the circumstances, or background factors, associated with the death of Constable Irwin, focusing on critical junctures, information and events identified by the Coroner.

Semyraha had been living at times with his partner and her two daughters, aged eight and nine, since he was released from prison in April 2007. His release from remand prison followed charges against him being dismissed. He had been held for five months on charges relating to the burglary of a liquor store. He had been denied bail because he was already on bail in relation to unspecified alleged offences committed in the city of Toowoomba in January 2007. While in prison he was issued with a notice to appear at a magistrates court for 'allegedly entering a pharmacy' in the Brisbane suburb of Wellers Hill 'with intent to commit and indictable offence' - just prior to the arrest that led to his incarceration (Office of the State Coroner, 2009a, p4). The bail conditions for the Toowoomba charges required he report regularly at the Ferny Grove Police Station. He failed to do this on several occasions and was issued with a notice to appear at a magistrates court on June 19. He failed to attend the court and a warrant was issued for his arrest.

In the meantime, Semyraha has been excused from attending the court on the date set down for the committal hearing in relation to the Wellers Hill charges. The investigating Officer - Officer B - was unaware of this and attended the court where he intended to issue Semyraha with an order to obtain his fingerprints. The Officer made enquiries and discovered that Semyraha was due to be arrested over the Toowoomba charges. He sent a message by computer to Ferny Grove Police Station on July 11 . When he received no response he phoned the station on July 17 and spoke to the shift supervisor - Officer $\mathrm{C}$ - who located the matter on the police computer. Officer B explained he was going to be on leave from the next day and needed the fingerprints as soon as possible.

During the phone conversation Officer B drew Officer C's attention to warnings about Semyraha on the police computer system. The warnings stated that he was known to carry firearms and knives and 'had a propensity to evade police'. One warning also stated, 'previous for armed robbery/assault may assault police to avoid arrest'. Another stated, 'May carry firearm. Previous for sawn off .22 cal rifle' (Office of the State Coroner, 2009a, p5).

In response to Officer B's request for urgency, Officer C - the shift supervisor allocated the warrant to Irwin and Officer A, whose shift began at 10pm. The officers were supplied with a copy of Semyraha's photo with the address written on the bottom. Officer A later reported that at this time the shift supervisor also informed him there were 11 warnings about Semyraha on the computer system. Officer A stated he had read the warnings and that Officer $\mathrm{C}$ had also read the warnings to the two officers. Officer A questioned the need to perform the job at that time. He suggested it was inappropriate to take someone from their home at night over 'minor matters' and questioned the legality of using the arrest for the bail breach to execute the finger 
print order. He suggested it would be better for the arrest to be performed by a day shift crew. At the inquest he also stated that safety was another concern behind his comments. However,

He agreed he did not advise [Officer C] of his unease as he did not wish to be seen as being overly cautious or factious. As a junior officer [a constable] it was important for him to be seen as a cooperative member of the team (Office of the State Coroner, 2009a, p6).

No mention was made of whether Irwin - a 'rookie' with just under a year's service had any concerns.

As it turned out, the two officer crew were caught up with other jobs for the entirety of their shift. When they began duty the next day at $10 \mathrm{pm}$ they were assigned the warrant as their second job. There was no discussion between the supervisor and the two constables, or between the constables, about the warnings or about a strategy for executing the warrant.

Semyraha's residence was a detached house set on a block of land (Figure 1). After parking the car Officer A led the way up the front stairs and along a short veranda to the front door. Officer A knocked on the glass of a window adjacent to the door. A dog inside the house started barking and someone was heard coming to the front door, but the door was not opened. Irwin left the veranda and circled the house. When he returned, Officer A suggested that the occupants were not going to answer and that they should leave. Irwin said he had seen a woman in the house and that they should try again. Officer A then knocked on the front door and called out, 'Ferny Grove police, open up' (Office of the State Coroner, 2009a, p7). Irwin then went to the back of the house and knocked on the back door. Officer A left the front intending to catch up with Irwin. The back door was opened by Semyraha and Irwin stepped into the kitchen. Semyraha was observed by his de facto holding a gun while talking to Irwin. Irwin appeared to struggle with Semyraha before turning and leaving the house. Semyraha followed, and while Irwin was going down the steps the gun was discharged.

Figure 1 about here

As Officer A was heading around to the rear of the house he heard voices and returned to the front door, expecting Irwin to bring Semeyraha out the front door. As he was walking up the front steps he heard signs of a struggle and headed back to the rear. En route he heard Irwin call out, 'gun!', then the shot. Then he heard Irwin yell, 'I've been shot, I've been shot!' (Office of the State Coroner, 2009a, p8). He then made his way back to the patrol car and radioed for help. The call was made at $10.47 \mathrm{pm}$.

As noted, a siege then took place. Early in the siege an officer from the dog squad performed a partial search of the yard looking for Irwin but he was unable to locate him. The presence of two dogs that had got out of the house was something of a deterrent. Several attempts were made by telephone to persuade Semyraha to surrender and he indicated that he was about to do this on several occasions. The two 
women and two children were allowed to exit. The siege ended when the SERT team stormed the house at $1.20 \mathrm{am}$, minutes after a shot was heard.

\section{Findings on causation and responsibility}

The Coroner made a number of findings in relation to the immediate causes of death of the two men. Irwin was found to have been shot dead by Semyraha. The officer's blood did not contain any drugs or alcohol, and his body had no injuries other than the wound from the fatal gunshot. According to testimony from a ballistics expert, the bullet matched a Luger pistol found under Semyraha's body, as did a casing found in the backyard. The bullet,

entered the upper quadrant of his back and exited the front of his chest. It perforated the left lung and his heart. The bullet lacerated the mitral valve and transacted the left anterior descending artery. It was an un-survivable injury that would have caused death in seconds or minutes. Not even immediate surgery would have been successful. (Office of the State Coroner, 2009a, p. 11)

Semyraha was found to have committed suicide. He left a suicide note behind and had indicated that he would commit suicide in telephone conversations with his mother during the siege. The autopsy revealed his blood contained high levels of amphetamines. He had a gunshot wound to the head. Blackening around the entry point indicated that the gun had been held against his head. The bullet was found in the kitchen wall in a position consistent with the gun being fired by Semyraha from the position where his body was located. The bullet also matched a casing found in the kitchen and the Luger pistol found under his body. (An examination of the weapons of the SERT officers found they had not been fired.) The bullet passed through Semyraha's brain and was described by the Coroner, on the advice of the Medical Examiner, as 'un-survivable'. Later in the day, after being taken to hospital, the life support system for Semyraha was turned off by the authority of his mother. The Coroner also reported that the circumstances of Semyraha's death influenced his partner to later commit suicide.

The Coroner identified a number of background or indirect causal factors behind Irwin's death. He began with a perhaps unexpected condemnation of the correctional system in Queensland He stated that Semyraha had been in a 'drug induced psychosis' in the weeks leading up to the fatal attack, and went on to state that:

Mr Semyraha spent 11 of the last 15 years of his life in youth detention or jail. When he was last released from jail three months before his death he was still drug addicted, devoid of any vocational skills and according to his mother, not coping with life. That he would continue to abuse illicit drugs was as predictable as the crimes that he would commit to fund their acquisition...

As is so often the case, police officers were left to deal with the failure of juvenile justice and corrective services to address Craig Semyraha's destructive behaviour. (Office of the State Coroner, 2009a, p13)

Turning to the police, the Coroner reported that there was no evidence that any of the officers involved had shown 'callous disregard for the safety of themselves or their 
colleagues' (Office of the State Coroner, 2009a, p13). At the same time, the Coroner claimed 'it appears that in some respects they failed to apply their training and/or made errors of judgement' (Office of the State Coroner, 2009a, p13). The Coroner took advice from the Police Service that in pre-service and annual in-service training all officers received instruction in risk management procedures, which:

Urges them to maintain situational awareness and to identify risks by undertaking continuous threat assessments as they move around the dynamic and frequently volatile environment in which they operate (Office of the State Coroner, 2009a, p14).

On this basis, the Coroner argued that the decision to execute the warrant on Semyraha was not a reasonable decision. All of the following factors should have militated against the decision: Semyraha's record of violent offences, the 11 warnings on the police computer system, the likelihood that he had concealable firearms, the lack of visibility at night, the lack of knowledge about the layout of the premises, and the lack of knowledge about the occupants. The latter point entailed an implied criticism that the siege could have turned into a catastrophic murder-suicide. There was also an implied criticism that the warrant should have been executed earlier but had apparently been left idle. This partly underlay Officer B's request for its execution so he could obtain Semyraha's fingerprints. He was criticised for pressuring the supervisor - Officer $\mathrm{C}$ - to make the matter a priority. In her testimony, Officer $\mathrm{C}$ described her view of the execution of the warrant as follows:

An easy pinch... a walk straight in, straight out job ... You walk in, you pick the person up, he goes in, you process him ... it's a straight up and down walk in (Office of the State Coroner, 2009a, p15).

In his critique of this description, the Coroner cited Semyraha's mother's view, that this,

might be the case if an officer was coming to arrest her for an unpaid speeding ticket but as the officers in this case well knew, the warrant they were seeking to execute did not relate to a law abiding middle aged woman (Office of the State Coroner, 2009a, 15).

Officer $\mathrm{C}$ testified she ignored the warnings on the computer system because she thought they were out-of-date, did not relate to the offender's current residence, and related more to his propensity to avoid capture. The Coroner specifically rejected this view, arguing that Semyraha had been involved in crime for at least the last 15 years without any sign of changing his ways. Office A had also argied that the supervising officer had described Semyraha as 'dangerous' (Office of the State Coroner, 2009b, p2-15).

During the hearing, testimony was provided that in Queensland 'warrants are frequently executed at night without any adverse consequences' (Office of the State Coroner, 2009a, p15). This view was also condemned:

That doesn't mean the practice is not dangerous. Rather, it suggests prevalence of a phenomenon referred to as 'risk normalisation' - a process whereby people 
habitually undertaking dangerous tasks come to view them as benign - they become complacent. (Office of the State Coroner, 2009a, p15)

Officer $\mathrm{C}$ was also criticised for ignoring the obvious cues from Officer $\mathrm{A}$ that he was concerned about the job. The Coroner argued that the concerns of junior staff must be considered, even when expressed tangentially. It was especially important that this be recognised in 'a macho, results oriented environment, in a hierarchical organisation like a police service' in which a junior officer will normally seek to hide their fears (Office of the State Coroner, 2009a, p16).

The Coroner also dealt with the potential defence that the police could not have known that Semeryaha probably thought he was being arrested for the Kippa-Ring robbery. The Coroner argued that this was not an excuse because the unexpected is 'a key component of a threat assessment - do not assume what you don't know won't hurt you' (Office of the State Coroner, 2009a, p16).

Criticism was also made of the complete lack of any plan for executing the warrant. The supervisor was criticised for not developing a plan with the two officers, and the two officers were also criticised for not developing a plan between them and not communicating properly during the operation.

\section{Recommendations for prevention}

The Coroner prefaced the recommendations section of his report by stating:

I acknowledge the significance of Constable Brett Irwin dying while serving the community as a police officer. Police officers confront danger so the rest of us can live more safely. When they die doing so, we are more deeply indebted to them. I sadly admit that debt knowing it can never be repaid. At the very least, we are obliged to do all we can to reduce the likelihood of deaths occurring in similar circumstances (Office of the State Coroner, 2009a, p13).

With this in mind the Coroner set down the following three recommendations, developed from his findings (Office of the State Coroner, 2009a, pp16-17):

\section{Recommendation 1 - Arrests and the execution of warrants}

I recommend the QPS (Queensland Police Service) review its policies and training to ensure all officers appreciate the potential danger involved in apprehending suspected offenders and the need for a conscious and explicitly articulated threat assessment and the development of at least a verbal operational plan whenever circumstances permit.

\section{Recommendation 2 - Obligation to consider safety}

I recommend the QPS review its policies and training to ensure all officers recognise the paramountcy of safety and their obligation to raise any safety concerns and the obligation of supervisors to support and encourage junior officers who do so.

\section{Recommendation 3 - Constable Irwin scenario}


I recommend the QPS utilise the powerful learning potential of the circumstances of this sad case by creating a training scenario that explicitly recognises the mistakes that were made and their consequences.

\section{Critique: Towards best practice in police officer safety}

The Coroner's report appears to have appropriately identified weaknesses in attitudes and procedures that led to Irwin's death. At the same time, there are a number of surprising absences in the report. An attack was made on the corrections system for its failure to address Semyraha's drug addiction and offending behaviour. However, no mention was made of the court system and the release of Semyraha despite the fact there were two sets of charges remaining against him. Another surprising absence in the Report is the lack of reference to the origin of the murder weapon. The Inquest heard from police that the Luger was most likely a World War One antique that did not appear on police firearms databases (Office of the State Coroner, 2009b, p2-4). Nonetheless, the issue of gun control could have received more attention in the recommendations. More surprising, however, was the lack of commentary on safety vests. Scientific advice should have been sought about whether or not a safety vest might have saved Irwin's life. Counsel for Irwin's family made the issue of body armour a key point in its submission. The Police Service reported that vests were available in the officers' car but maintained their use was and should be discretionary (Office of the State Coroner, 2009b. pp4-5, 2-4, 4-17). This is despite the fact that US research indicates lightweight body armour has saved the lives of over 3,000 officers and that not wearing body armour increases an officer's chance of being fatally injured by a factor of 14 (Taylor, et al., 2009, p11).

However, the most significant issue neglected by the Coroner concerns the departmental policy on arrest by warrant - or the absence of such a policy - when threats are apparent. The Coroner's report seems to imply that the arrest could have been carried out by the two patrol officers under slightly different circumstances: in daylight, with better reconnaissance and a more cautious planned approach. However, the evidence about Semyraha's tendency to violence and the likelihood that he would resist arrest should have resulted in an explicit finding against this alternative. The Coroner merely recommended the Police Service review its 'policies and training' in relation to risk management. There was no explicit requirement to modify standard operating procedures. The recommendation seemed to support the training system that places the prime obligation for decision making on the officers involved in an operation. However, a key implication of the inquest is that this approach is too open and gives operational officers far too much discretion. The larger literature on police fatality prevention shows that much more binding and specific policies are required to prevent the tendency of police to act recklessly. This applies across a variety of police tasks, including high speed pursuits and traffic stops (Allard \& Prenzler, 2009; Chapman, 1997; Federal Bureau of Investigation, 2007; Mayhew, 2001; Payne \& Fenske, 1997; Pinizzotto, Davis \& Miller; 2002).

Analysis of the Irwin case should have led to a recommendation that (a) a mandated formal risk assessment be conducted before any warrants are executed, that (b) the outcomes of the assessment be written down and preserved and that (c) any sign of danger should result in the matter being handed over to a special operations team and treated as a high risk operation. Signs of danger should be evaluated on a low 
threshold: if (a) the charge is for a violent offence, if (b) there are any previous charges or convictions for violence or (c) if there are any other indicators (such as a record of threats) that might be read as risk factors. Regular patrol officers should only be involved in arrests under these circumstances when the matter is extremely urgent and special operations teams are unavailable. In these cases officers should be required to wear body armour, conduct a formal risk assessment and collectively develop a formal operational plan. One implication of this proposal is that many police departments would need to increase the number of special operations teams and widen their deployment geographically.

These recommendations are consistent with the situational crime prevention technique of 'rule setting', as well as 'extend guardianship' (SERT) and 'target hardening' (protective vests) (Clarke \& Eck 2003). In fact, the mandatory use of protective vests for regular police duties is receiving support in a number of jurisdictions (e.g., Taylor, et al. 2009). These include the United Kingdom, where the wearing of vests is fairly commonplace but where chief officers have wide discretion on policy (Pennington 2007). There are other policy implications that were left undeveloped by the Coroner. More attention should have been given to tighter gun control ('controlling tools/weapons'), earlier intervention with persons with mental illness and a less liberal approach to repeat offenders facing outstanding charges. The Coroner was right to draw attention to the failings of the correctional system, but the policy implications of this were not developed. A potentially useful model here, focused on close supervision of parolees, is the Prolific and Priority Offenders (PPO) Program in the UK (Home Office, 2009; Roberts, 2007).

The three recommendations made by the Coroner involved handing responsibility to the police for improved prevention. However, there is no guarantee that an adequate response will be forthcoming. In fact, it is unlikely given research showing government departments in Australia generally ignore Coroners' advice (Queensland Ombudsman, 2006). The Police Service submission opposed specific mandated safety procedures, citing the need for operational flexibility and officer discretion (Office of the State Coroner, 2009b, p4-17). The final missing ingredients in the report are therefore (a) a mechanism requiring police report back to the Coroner on the implementation of recommendations, (b) the Coroner's office independently assess the level of implementation and (c) the results be reported to parliament.

\section{Conclusions}

The death on duty of Constable Brett Irwin was not a random uncontrollable event. It was the result of a sequence of events that evidenced poor procedures, poor management and poor policy. Nor were the circumstances of Irwin's death unique. They have been repeated many thousands of times in police work around the globe with equally fatal consequences. In many cases, similar circumstances have also resulted in injuries to police. All these deaths and injuries are the result of the lack of a scientific approach to policing. They result when police departments fail to develop and enforce procedures based on best practice principles derived either from in-house research or from the international policing and safety literature. It is hoped that the lessons from this close analysis of the circumstances of Constable Irwin's death will be applied and lives saved and injuries prevented. The key general lesson is that in many locations police need to take a far more cautious approach to their work, 
including with tasks that are often considered routine and which may be completed many thousands of time without harmful consequences. Specifically, this means that very high safety standards and thorough risk management procedures need to be applied in the service of warrants. Any indications of danger should result in the matter being handed over to special operations officers and treated as a major operation.

\section{References}

Allard, T., \& Prenzler, T. (2009). A Summary analysis of police deaths in Australia: Implications for prevention. International Journal of Comparative and Applied Criminal Justice, 33, 61-81.

Chapman, S. (1997). Murdered on duty: The Killing of police officers in America. Springfield IL: Charles C. Thomas.

Clarke, R.V., \& Eck, J. (2003). Become a problem-solving crime analyst. London: Jill Dando Institute of Crime Science, University College London.

Edwards, T. (1996). Felonious killings of state police and highway patrol officers: A Descriptive and comparative evaluation. American Journal of Policing, 14, 89105.

Federal Bureau of Investigation (2007). Law enforcement officers killed and assaulted 2006. Washington DC.

Home Office (2009) Prolific and Other Priority Offender Programme. London.

Kaminski, R., \& Sorensen, D. (1995). A Multivariate analysis of individual, situational and environmental factors associated with police assault injuries. American Journal of Police, 14, 3-48.

Kurby, R. (2004). End of watch: Utah's murdered police officers: 1853-2003. Salt Lake City: University of Utah Press.

Mayhew, C. (2001). Occupational Health and Safety Risks Faced by Police Officers. Canberra: Australian Institute of Criminology.

Meade, K. 2007. Police mourn colleague "taken by fate”. The Australian July 27:7.

Murray, D. and Doneman, P. 2007. Cute boy who became a killer. Sunday Mail July 22:11

National Law Enforcement Officers Memorial Fund (2009). A Tale of two trends: Overall fatalities fall, fatal shootings on the rise. Research Bulletin, December, 1.

National Occupational Health and Safety Commission (1999a) Work related fatalities involving emergency service workers in Australia, 1989 to 1992. Sydney.

National Occupational Health and Safety Commission (1999b) Worksafe News, October. Sydney.

Office of the State Coroner (2009a) Findings of Inquest: Inquest into the Deaths of Constable Brett Andrew Irwin and Craig Anthony Semyraha. Brisbane.

Office of the State Coroner (2009b) Transcript of Proceedings: In the Matter of an Inquest into Causes and Circumstances Surrounding the Deaths of Brett Andrew Irwin and Craig Anthony Semyraha. Brisbane.

Payne, D. \& Fenske, J. 1997. An analysis of the rates of accidents, injuries and fatalities under different light conditions: Michigan emergency response study of state police pursuits. Policing: An International Journal of Police Strategies \& Management, 20(2) :357-373.

Pelfrey, W., \& Covington, M. (2007). Deaths in custody: The Utility of data collected from County Coroners. Criminal Justice Studies, 20, 65-78. 
Pennington, C. (2007). Body armour dilemmas in the police. Retrieved 23 April, 2010, from http://www.publicservice.co.uk/feature_story.asp?id=8273.

Pinizzotto, A., Davis, E., \& Miller, C. (2002). Accidentally dead: Accidental line-ofduty deaths of law enforcement officers. FBI Law Enforcement Bulletin, 71, 8-13.

Police Roll of Honour Trust (2010) National Police Officers Roll of Honour and Remembrance. http://www.policememorial.org.uk/, accessed 9 March 2010.

Prenzler, T. (2006). Towards prevention: A Situational study of police deaths on duty in Queensland. Current Issues in Criminal Justice, 18, 147-164.

Queensland Ombudsman (2006). The Coronial recommendations project. Brisbane: Queensland Ombudsman.

Roberts, C. (2007). Continuing to display effectiveness: An Evaluation report on three years of the IRIS Project. Oxford: Oxford: Centre for Criminology, University of Oxford.

Smith, D., \& Webster, D. (2005). The Relative hazards of Australian police work. Australian Police Journal, 59, 41-43.

Smith, M., Kaminski, R., Alpert, G, Fridell, L, MacDonald, J., \& Kubu, B. (2009). A Multi-Method evaluation of police use of force outcomes: Final report to the National Institute of Justice. Washington, DC: U.S. Justice Department.

South Africa Police Service (2009) Roll of Honour, 2007-2008. Retrieved February 4, 2010, from www.saps.gov.za/saps_profile/honour/roll_honour2007_8.htm.

Taylor, B., Kubu, B., Kappleman, K., Gunaratne, H., Ballard, N., \& Martinez, M. (2009) The BJA/PERF Body Armor National Survey. Washington, DC: Bureau of Justice Administration (US Department of Justice) and Police Executive Research Forum.

United Nations Secretary General (2009). Message on International Day of Peacekeepers, 29 May 2009. Retrieved 4 february, 2010, from http://un2.amblique.net/files/files/peacekeepersday2009.pdf.

\section{Legislation}

Coroners Act 2003 (Queensland). 
Figure 1: Layout of Premises

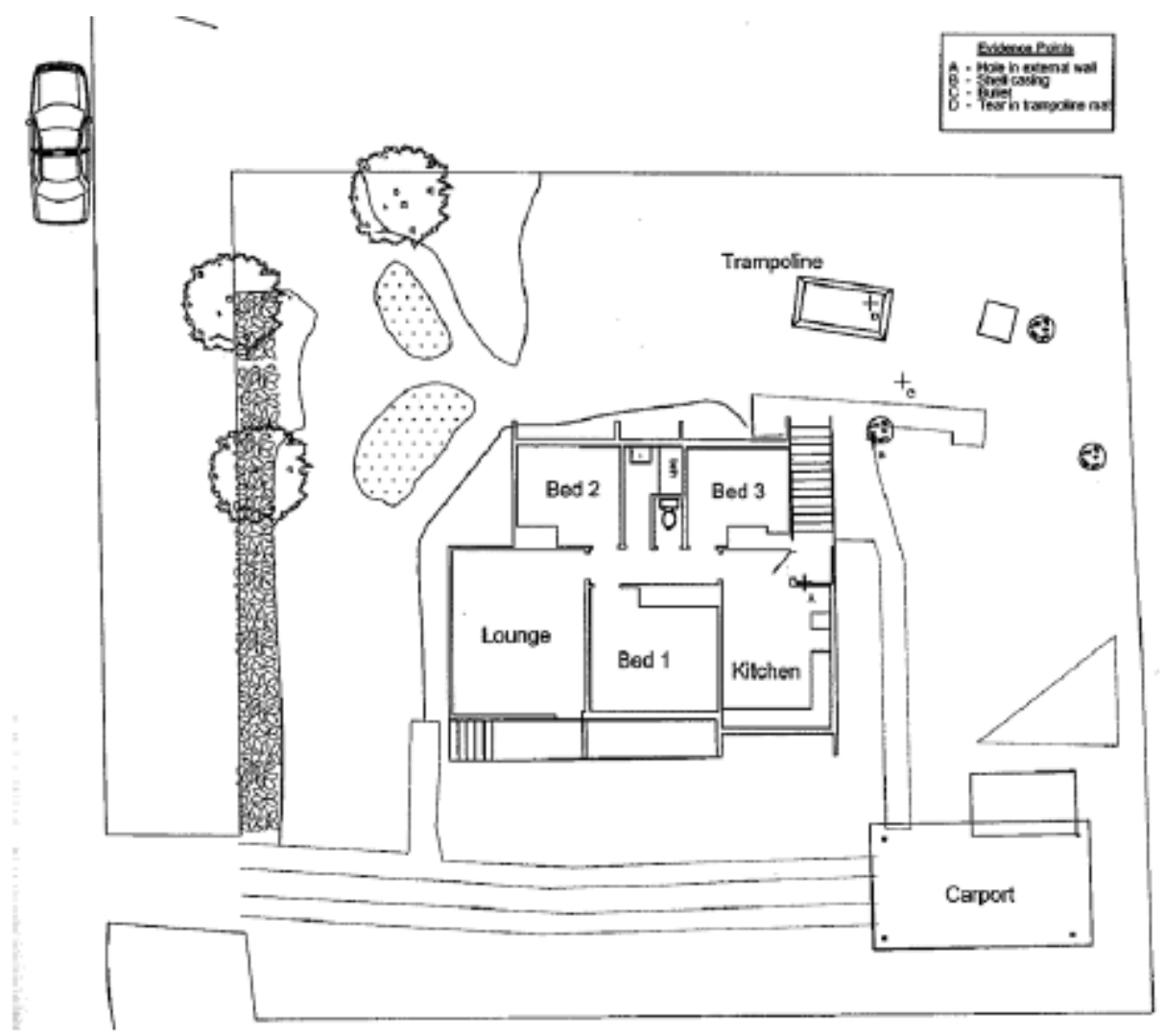

Used with permission. 